\title{
Cumhuriyet Dönemi Kent Parklarının Karaalioğlu Parkı Örneğinde İncelenmesi
}

\author{
Esat Furkan ENGIN ${ }^{1}$, Reyhan ERDOĞAN ${ }^{2 *}$ \\ ${ }^{1}$ Akdeniz Üniversitesi, Fen Bilimleri Enstitüsü, Peyzaj Mimarlığı Anabilim Dalı, 07070, ANTALYA \\ ${ }^{2}$ Akdeniz Üniversitesi, Mimarlık Fakültesi, Peyzaj Mimarlığı Bölümü, 07070, ANTALYA
}

\section{Öz}

Araştırmanın amacı, Cumhuriyet dönemi peyzaj mimarlı̆̆ı anlayışını belirlemek ve o dönemde yapılmış olan eserlerin incelenerek günümüzdeki durumları hakkında çıkarımlar yapmaktır. Elde edilen verilerle Cumhuriyet dönemi parklarının yeniden tasarımı söz konusu olduğunda tarihi değerine saygı gösterilerek, tüm dünya tarafından kabul görmüş belirli kuramlar 1şığında gelecek nesillerle olan bağlantısının kurulması düşünülmüştür. $\mathrm{Bu}$ amaç doğrultusunda Antalya Karaalioğlu Parkı eski belediye alanı ve Atatürk stadyumu alanı incelenmiş ve öneriler geliştirilmiştir. Parkın tarihi, o dönemde yapılmış olan su kanalları, miradorlar, bitkisel düzenlemeler ve yapısal öğeler çeşitli kaynak taramaları ile ortaya çıkarılmıştır. Ortaya çıkan bu elemanların günümüz teknolojileri ile aslına uygun olarak ve yerinde yeniden canlandırılması hedeflenmiştir. Araştırma sonucunda, Erken Cumhuriyet döneminde yapılan parklarda, yeni Cumhuriyet anlayışına göre kendine has bir üslubun oluştuğu sonucuna varılmıştır. Bu üslup oluşurken, dönemin peyzaj mimarları, mimarları ve kent plancıları geçmiş dönemdeki park ve bahçe sanatlarından etkilenmişlerdir. Parklarda kimi zaman Barok stili, kimi zaman Rönesans etkileri, kimi zamansa antik kent planlarından bile esinlenmelere rastlanmaktadır. Bu tarzın genel özellikleri; geometrik formların hâkim olduğu, sonuca en net şekilde ulaşılabilen, karmaşadan uzak ve gösterişli bir yapısı olmasıdır. Örnek olan seçili alanda bu tarza uygun bir tasarım hazırlanmış, geçmiş ve bugün arasındaki farklar baz alınarak çıkarımlar yapılmıştır.

Anahtar Kelimeler: Cumhuriyet, park, tasarım, Karaalioglu parkı, Antalya.

\section{Evaluation of Republican City Parks in the Case of Karaalioğlu Park}

\begin{abstract}
The purpose of this research is to determine the concept of landscape architecture understanding in the Republican period and to make inferences about the present conditions by examining the works made at that time. In the case of the redesign of the parks of the Republican period, the historical value is respected and the establishment of a link to the next generation in the light of certain theories accepted by the whole world has been considered. In line with this aim, the area of Antalya Karaalioğlu Park former municipality area and Atatürk stadium was examined and recommendations were developed. The history of the park, the water channels, the mirados, the vegetational and planting arrangements and the structural items made at that time were revealed by various source research. It is aimed that these emerging elements will be revitalized in place and in accordance with today's technology. As a result of the research, the parks constructed in the early Republican period had a unique style according to the new Republican concept. In this style, landscape architects, architects and urban planners of the period were influenced by past park and garden arts. The parks are inspired by different styles such as Baroque, Renaissance and from ancient city plans. General characteristics of this style are that the general plan form is dominantly geometric, and the result is a clear, distant, and flashy structure that can be reached in the clearest possible way. In the selected example area, an appropriate design was prepared for this item and inferences were made based on the differences between past and present.
\end{abstract}

Keywords: Republic, park, design, Karaalioğlu park, Antalya. 


\section{Giriş}

Farklı dönemlerde ve kültürlerde oluşturulmuş bütün kentsel açık yeşil alanlar ve kent parkları çeşitli sanat akımlarından etkilenmiştir. Bu alanlardan bazıları peyzaj özellikleri bakımından da içinde bulunmuş olduğu dönem ile ilgili sosyal ve kültürel detayları günümüzde de bizlere yansıtmaktadır. Fakat pek çoğu çağın ihtiyaçlarına ve gelişimine karşı koyamayarak yok olmuş ya da özgün niteliklerinden pek çoğunu kaybetmiştir. Hâlbuki kentlerdeki tarihi ve kültürel peyzaj değerleri, o kentin yaşam kalitesini artıran en önemli unsurdur (Olgun ve Yılmaz, 2014; Çınar Altınçekiç vd, 2018). Günümüze kadar gelebilmiş tarihsel mekânların korunması kent yaşamının sürdürülebilirliği ve kalitesi için büyük önem taşımaktadır.

Pek çok bilimsel çalışma da tarihi ve kültürel değerlerin kent için önemini destekler söylemleri içermektedir. İnsanın yaşamını sürdürdüğü içinde bulunduğu çevre salt fiziksel değildir. Bu çevreyi sadece doğal unsurlarla tanımlamak da doğru değildir. İnsan yaşam alanı her şeyin ötesinde zihinsel-kavramsal bir mekândır. Bu kavramsal mekânı oluşturan en önemli unsurlardan birisi de kültürdür. Kültür insanların yaşam biçimlerini anlatır. İnsan var olabilmek, ihtiyaçlarını sağlayabilmek için yaşadığı çevreyi kendine göre düzenlemek, değiştirmek zorunda kalmıştır. Diğer taraftan insan yaşadığ ç̧evreye göre kendini uyarlamak, değiştirmek ve şekillendirmek gereği duymuştur. Yüzyıllar boyu insan ve çevresi birbiri ile olan etkileşimini aralıksız bir şekilde sürdürmeye devam etmiş ve sürdürmeye de devam edecektir. Sonuç olarak Dünya'da insan etkisinde kalmayan bir peyzaj kaldığını söylemek imkânsızdır (Baylan, 2003; Özsüle, 2005; Bekdemir, 2010).

Ingerson (2003)'a göre, kültürel peyzajı algılamanın belirli aşamaları vardır. Bunun için öncelikle peyzajı oluşturan önemli elemanları, sonra bu elemanların özelliklerini tanımlamak gerekir. Peyzaj elemanlarının birbirleriyle, tarihi olaylar, eğilimler ve insanlarla olan ilişkilerini ortaya koymak, peyzajı bir kültürel kaynak olarak algılamayı sağlamaktadır. Çoğu durum için bu elemanlar dinamik ve zamana bağlı olarak değişkendir. Çoğu durumda tarihsel olarak taşıdığı önem, peyzajın fiziksel ve kültürel evrimini uzunca bir zaman dilimi boyunca etkilemektedir (Arslan, 2010). Alanların kullanıcıya görsel ve kültürel doygunluk sağlaması ve kentlilik bilincini aşılayabilmesi için düzenlemede kullanılacak elemanlara dikkat edilmesi gereklidir. Avrupa'nın birçok kentlerinde kentsel mekanlar, tarihi ve mimari değerleri biraraya gelerek, sanat müzeleri haline dönüştüğ̈̈ unutulmamalıdır (Çınar, 2005).

Antalya geçirdiği tüm dönüşümlerle birlikte kent içerisindeki halka açık kullanımlarda yaşanan dönüşümlerle de öncü şehirlerden biri olmayı başarmıştır. Parkları, meydanları, ortalarından su kanalları geçen caddeleriyle gerçek kentli yaşamının ve Cumhuriyet döneminin getirmiş olduğu estetik ve modernizm anlayışının hakkını vermeye çalışmıştır. Çalışma alanı olarak seçilen Karaalioğlu Parkı'da Cumhuriyet döneminde, devlet eliyle ve farklı cemiyetlerin katkılarıyla yapılmış olan, o dönemdeki peyzaj mimarlığı tasarım anlayışını yansıtan önemli eserlerden bir tanesidir.

$\mathrm{Bu}$ çalışmanın amacı, Erken Cumhuriyet dönemi peyzaj mimarlığı anlayışının günümüzdeki örneklerini incelemek, var olan eserlerin yerinde korunmasına ilişkin öneriler getirmek ve gelecek nesillerle aralarındaki bağı güçlendirmektir. Erken Cumhuriyet döneminde yalnızca mimaride oluşan kendine has üslubun dışında, peyzaj mimarlığı alanında da geliştirilmiş olan üslubun günümüz koşullarıyla sürdürülebilirliğinin sağlanması hedeflenmiştir. Bu bağlamlardan yola çıkılarak seçilen Karaalioğlu Park’1 dönüşmekte olan yapısı ile dönemin eserlerini koruma hususunda yaşanılan sıkıntıların somut bir örneği olmuş, yeni önerilerin geliştirilmesi ve yerinde korunması hususunda fikirler ortaya atılmasına olanak sağlamıştır.

\section{Materyal ve Metot}

\subsection{Materyal}

Antalya güneyinde Akdeniz kuzeyinde denize paralel uzanan Toroslar ile çevrili olup, doğusunda İçel, Konya ve Karaman, kuzeyinde Isparta ve Burdur, batısında Muğla illeri ile komşudur. Sahip olduğu $20815 \mathrm{~km}^{2}$ 'lik yüzölçümü ile Türkiye yüzölçümünün \%2,6'sını oluşturmaktadır (Sarı, 2010; Olgun ve Erdoğan, 2016). Antalya sahip olduğu doğal ve kültürel zenginlikleri ve son yıllarda yaşanan gelişmelerle birlikte Dünya tarafından tanınan Türkiye'nin en önemli kentlerinden birisidir (Erdoğan vd., 2016).

Araştırma alanı olarak Antalya il sınırları içerisinde yer almakta olan Karaalioğlu parkı içerisindeki belediye binası ve çevresindeki alan seçilmiştir. Yaklaşık 70.000 metrekarelik bir alana sahip olan Karaalioğlu parkı, Antalya’nın Muratpaşa ilçesi Kılınçarslan Mahallesi’nde yer almaktadır. Park, tarihi Kaleiçi bölgesine ve dönemin ilk modern yapılarına komşuluk etmektedir. Parkın Kuzeybatısında Atatürk evi ve eski belediye binası bulunmaktadır. Alanın Güneydoğusunda ise şimdi yıkılmış durumda olan Antalya stadı bulunmaktaydı 
(Anonim, 2019) (Şekil 1). Bu kapsamda tarihsel bir geçmişe sahip olan ve seyir terası niteliği taşıyan Karaalioğlu parkı taşıdığı özellikleri ve büyüklüğü ile kent parkı niteliği taşımaktadır.
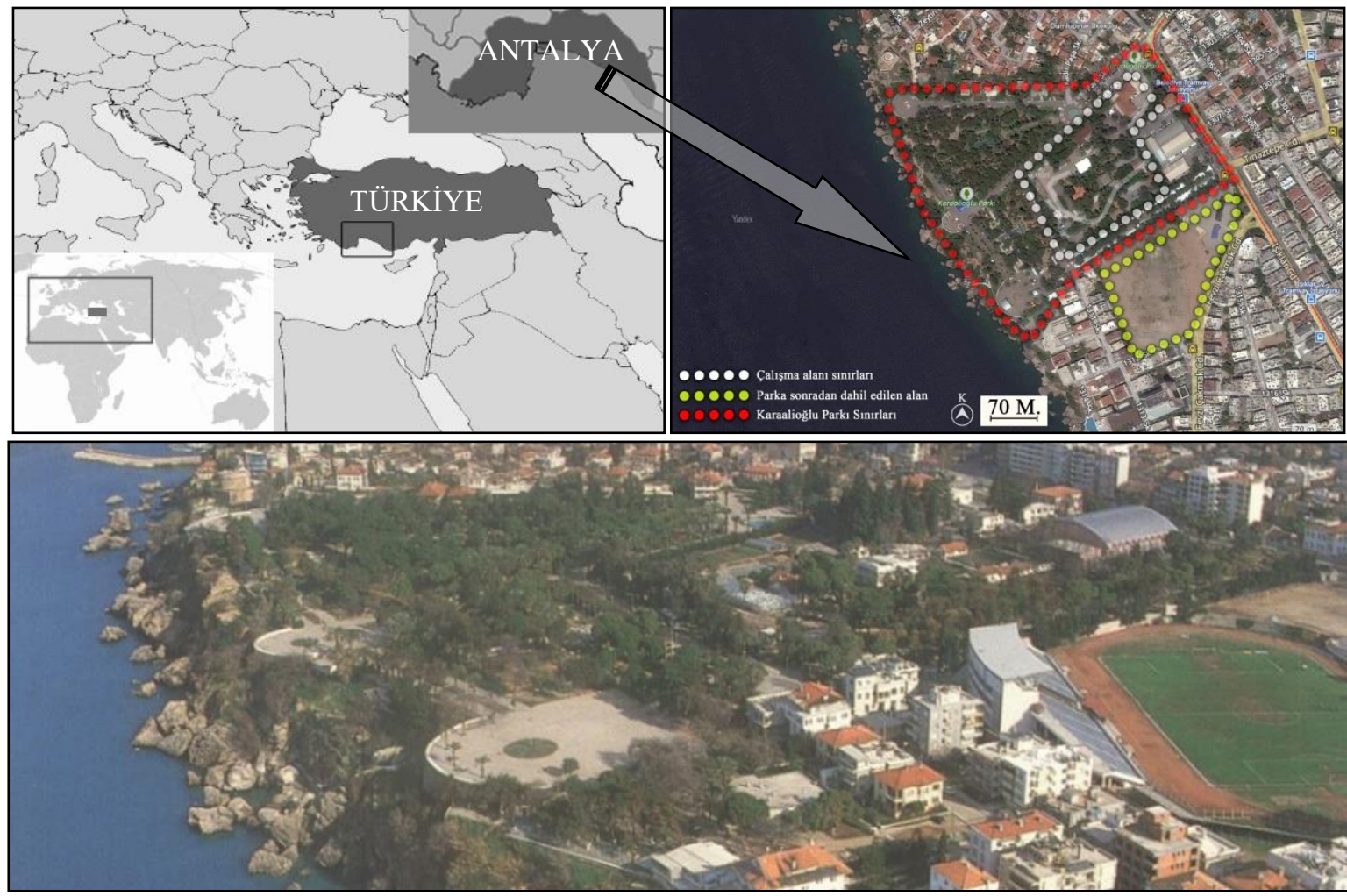

Şekil 1. Araştırma alanının konumu (Olgun, 2019), Karaalioğlu parkının sınırları ve genel görünümü (Sayan vd., 2008)

\subsection{Metot}

Araştırma yöntemi iki aşamalı olarak gerçekleştirilmiştir. Araştırma yönteminin ilk aşamasına, Karaalioğlu parkına ait verilerin toplanması, literatür taraması, konu ile ilgili uzman ve kuruluşların çalışmalarının incelenmesi ile başlanmıștır. Alanın geçmişten günümüze kadar çizilmiş olan plan ve projelerinin temin edilmesi, parkla ilgili doğal ve sosyokültürel yapının analizi yapılarak çalışmalara devam edilmiştir. Çalışma alanına ilişkin geçmişten günümüze fotoğrafların temini, mevcut durumunun fotoğraflanması, vejetasyon durumu, günümüzdeki fonksiyonlarının araştırılması ve altlık olarak kullanılacak veriler üzerinden alan ile ilgili kararların alınmaya başlanması hedeflenmiştir.

Araştırmanın ikinci aşamasında Karaalioğlu Parkı belediye binası çevresinin yeniden tasarlanması konusunda alana ilişkin vaziyet planı, uygulama imar planları, proje, rapor, fotoğraf ve dokümanlar ile ilgililerle yapılan görüşmeler materyal olarak değerlendirilmiştir. Daha sonra fotoğraflardan yararlanılarak alandaki ilk donatı tipleri belirlenmiş ve buna göre bir tipoloji oluşturulmuştur. Böylece donatı formları, teknik çizimler, kesit ve görünüşlerle desteklenerek bir bütün halinde sunulmuştur. Karaalioğlu parkı içerisindeki belediyeye ait olan alan ile ilgili sayısal veriler bilgisayar destekli tasarım programlarına (Autocad, Photoshop, 3ds Max Design, Lumion) aktarılmış ve alana ilişkin Cumhuriyet dönemini yansıtan tasarım kararları verilmiştir.

Karaalioğlu Parkı'nın içerisinde bulunan eski belediye binası çevresinin incelenmesi ve yeniden tasarlanmasında, Cumhuriyet dönemindeki peyzaj mimarlığı anlayışı irdelenmiş ve bu anlayış ışığında yeniden fikirler üretilmiştir. Antalya Büyükşehir Belediyesi'nin hazırlamış olduğu modern anlayışlı tasarım projesi ile birlikte erken Cumhuriyet dönemine göre hazırlanmış olan proje karşılıklı değerlendirilmiştir. Değerlendirmeler sonucunda erken Cumhuriyet dönemini yansıtan ve o dönemin tasarım anlayışına 1şık tutan en özgün proje ortaya konulmaya çalışılmıştır. 


\section{Bulgular}

Cumhuriyet'in kuruluşu ve Mustafa Kemal'in vefatı olan 1923 - 1938 yılları arasındaki dönem Erken Cumhuriyet dönemi olarak belirtilmektedir. $\mathrm{Bu}$ dönemin belirgin özelliği yeni bir yönetim biçimine ve onun hukuki-idari yapısının oluşturulmasına denk gelmesi ve de tarihin sıfırlanması projesi olarak eskiden köklü bir kopuş üzerinden kendini tanımlayan milliyetçilikle harmanlanıp şekillendirilmiş bir zihniyet yaratmayı amaçlamasıdır (Akman 2011).

Antalya Karaalioğlu Parkı II. Dünya Savaşı'nın sürmekte olduğu dönemde, (1935-1944 yılları arasında) inşa edilen Cumhuriyet döneminin ilk parklarındandır. Günümüzde Antalya kentinin en eski ve tarihsel değere sahip tek parkı olma özelliğini taşıyan Karaalioğlu Parkı, kent merkezinde; deniz düzeyinden 35-40 m yükseklikteki falezlerin üzerinde $48.000 \mathrm{~m}^{2}$ alan üzerinde kurulmuş bir kent parkıdır. Park her dönemde Antalya'da gezilecek görülecek yerler arasında yer almış; Antalya’yı tanıtıcı kitaplarda kentin önemli özelliklerinden birisi olarak ele alınmıştır (Sayan vd., 2008).

Karaalioğlu parkı Cumhuriyet döneminin ilk parklarındandır. Taşıdığı kültürel ve manevi değerler ile Antalya'nın simge yapılarından birisi olmuştur. Cumhuriyet dönemi tasarım anlayışı içerisinde planlanan park, geçmişten günümüze kadar çok çeşitli dönüşümlerden geçmiştir ve dönüşmeye de devam etmektedir (Tablo 1).

Tablo 1. Kronolojik olarak Karaalioğlu Parkının yapım ve tasarım aşamaları

\begin{tabular}{|c|c|}
\hline TARİH & FAALIYYT DURUMU \\
\hline 20. yy.'ın başları & Park alanı mesire alanı olarak kullanılmıştır. \\
\hline 1927 & $\begin{array}{l}\text { Karaferiye'den Kestriye çingeneleri gelmiş. Buraya yerleşmişlerdir. Yerleşim alanı } \\
\text { olarak kullanılmıştır. }\end{array}$ \\
\hline 1935 & Parkın yapımına başlanmıştır. \\
\hline 1940-1945 & $\begin{array}{l}\text { Parkın günümüze ulaşan son halinin projesi Mimar Necmettin Ateş tarafindan } \\
\text { hazırlanmıştır. }\end{array}$ \\
\hline 1943 & İsmet İnönü parkı ziyaret etmiştir. \\
\hline 1950 & Halkevi binasının Güneyinde zirai araştırma enstitüsü kurulmuştur. \\
\hline 2002 & $\begin{array}{l}\text { Park alanı yarışmaya açılmıştır. H. Kahvecioğlu ve N. Kahvecioğlu'nun hazırlamış } \\
\text { olduğu proje } 1 \text {. seçilmiş. }\end{array}$ \\
\hline 2016 & Antalya Atatürk Stadı’nın yıkımı gerçekleşmiştir. \\
\hline 2003/2004 & Park alanının Batı konumunda 1. Seçilen proje uygulamaya başlanmıştır. \\
\hline 2017 & $\begin{array}{l}\text { Antalya Büyükşehir Belediyesi yeni binasına taşınmıştır. Otopark ve işletme alanı } \\
\text { boşaltılmıştır. Antalya Kent Müzesi ihaleye açılmışır. Karaalioğlu Parkı Doğu } \\
\text { konumundaki eski belediye alanı ve stat alanının inşaatına başlanmıştır. }\end{array}$ \\
\hline
\end{tabular}

Parkın bugünkü görünümünü oluşturan proje; 1940-1945 yılları arasında uygulanmıştır. Vali Haşim İşcan'ın öncülüğünde, zamanın İl Özel İdare Müdür Muharrem Önal'ın başkanlığını yaptığı Antalya'yı Güzelleştirme Cemiyeti’nin katkılarıyla park düzenlemesi mimar Necmettin Ateş’e yaptırılmıştır (Çimrin, 2006) (Şekil 2).

Karaalioğlu Parkı inşaatı toplamda 3 yıl sürmüştür. Yapımı bittiğinde, Türkiye'de büyük bir ün yapmıştır. Park tamamlandığında genel olarak donatılar, rengârenk lambalı, fiskiyeli havuzlardan, lambalarla süslü pergolalardan, miradorlardan, merdivenler ve çiçekliklerden oluşmaktaydı (Şekil 3). Haşim İşcan bu parkı aynı zamanda bir Akdeniz Fuarı alanı olarak düşünmüştü ancak bu plan gerçekleşemedi (Çimrin, 2006). 


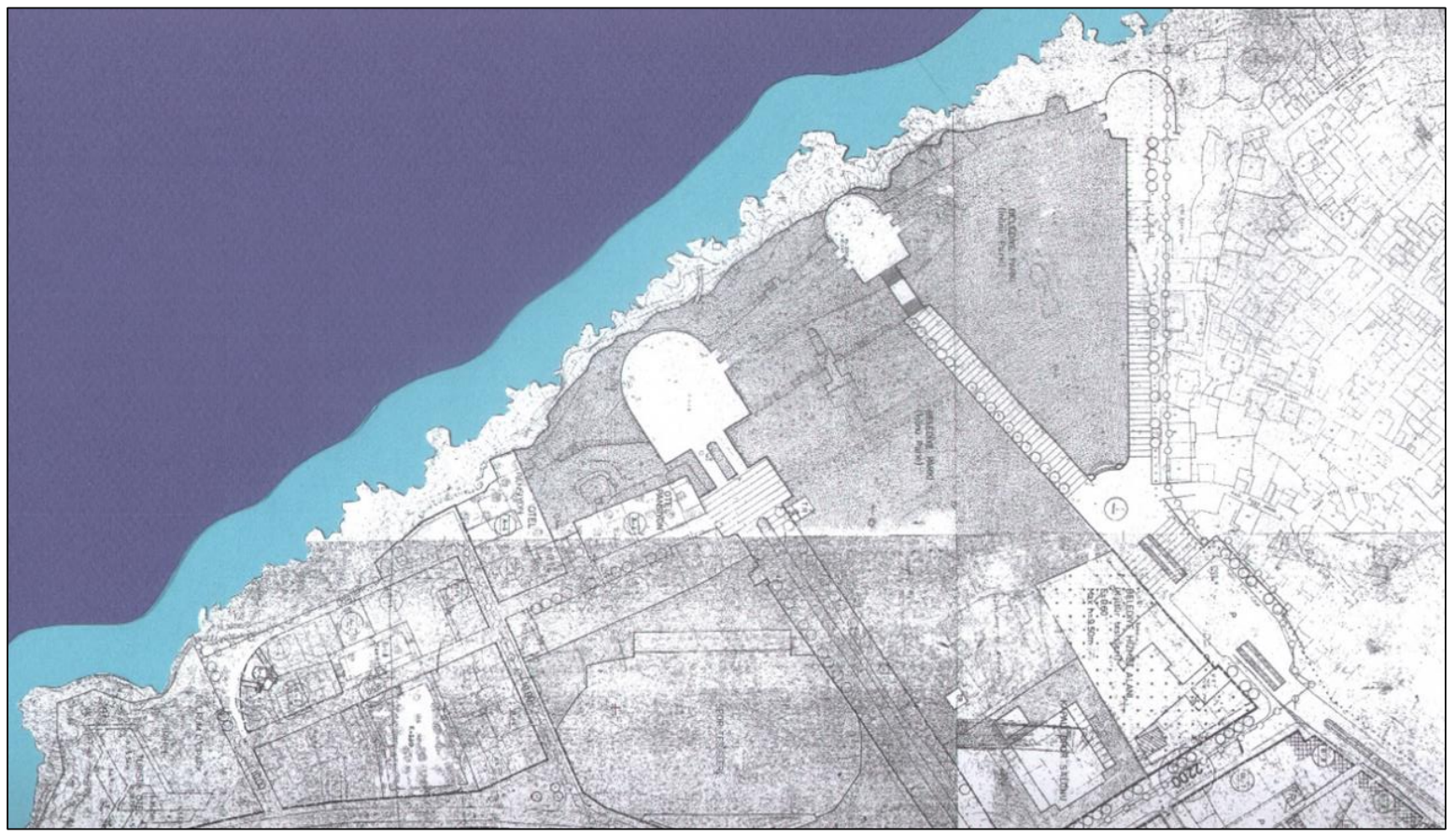

Şekil 2. Karaalioğlu Parkı'nın eski imar planı vaziyet durumu (Sayan vd., 2008)
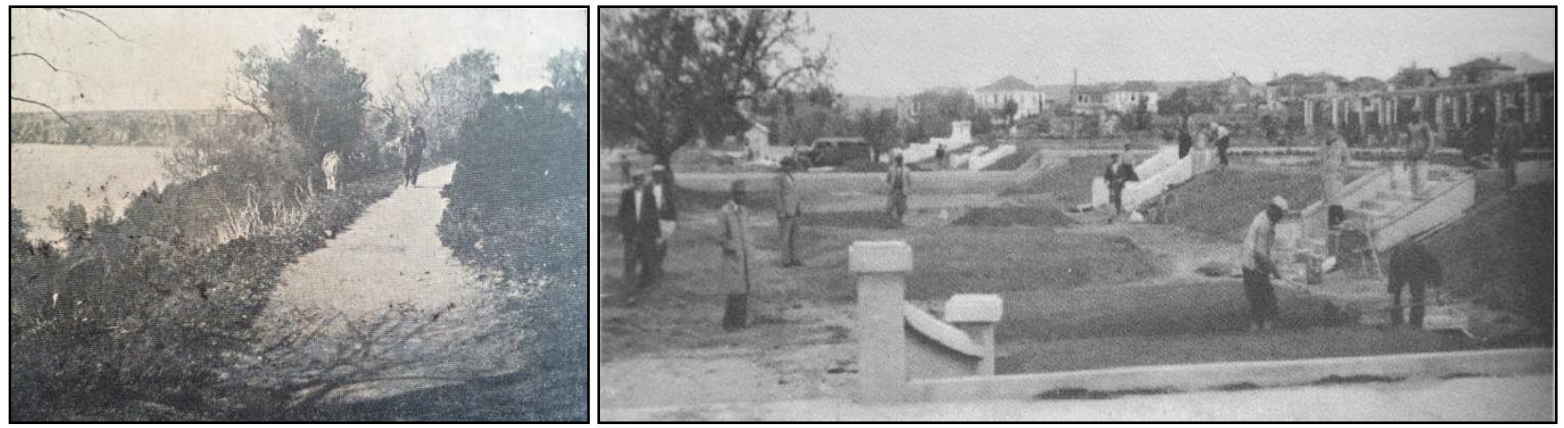

Şekil 3. Karaalioğlu parkının düzenlenmeden önceki bir görüntüsü (Vâ-Nû, 1944) ve park inşaatından bir görüntü (Çimrin, 2006)

\subsection{Karaalioğlu Parkı Erken Cumhuriyet Dönemi Tasarım Çalışmaları}

Cumhuriyet dönemi kent parkları Anadolu'nun dört bir yanında tekrar edilen, kolayca tanınan milli bir imge oluşturmuştur. Bu parkların karakteristik özellikleri ise ortalarında fiskiyeler olan geometrik şekilli havuzlar, düzgün çiçek tarhları, düzenli olarak ekilmiş ağaçlar, elektrik direkleri ve banklar bulunmasıdır (Bozdoğan, 2002). Karaalioğlu Parkı, erken Cumhuriyet dönemi kent parklarının sergilemiş olduğu karakteristik özelliklerin birçoğuna sahiptir ve bu özellikler bazı noktalarda günümüze kadar gelmiştir.

Parkın genel olarak tasarımı ve uygulaması dönemin koşulları dâhilinde öncelikli olarak su kanallarının ve yürüyüş yollarının inşa edilmesi şeklinde başlamıştır. İlerleyen süreçte ise havuzlar, promenadlar, bitki parterleri, açık çim alanlar, koruluk ve miradorlar ile dönemin yeni tasarım anlayışını yansıtan öğelerle son şeklini almıştır. Bu kapsamda park içerisinde tasarlanan yürüyüş yolları keskin ve düz bir hatta sahiptir. Parkın giriş bölümünden itibaren ana akslar karşılıklı gidiş ve geliş şeklinde tasarlanmıştır. Parktaki ortak kullanım alanları (çocuk oyun alanları, açık çim alanlar, gölgelik alanlar) genellikle sert, köşeli ve simetrik bir biçimde ayrılmıştır. Karaalioğlu parkı yürüyüş akslarının kapladığı toplam alan miktarı yaklaşık olarak $20.000 \mathrm{~m}^{2}$, dir. Karaalioğlu parkındaki diğer sert zemin ve seyir teraslarının toplam alan miktarı yaklaşık olarak $11.000 \mathrm{~m}^{2}$, dir. Karaalioğlu parkı içerisinde bulunan tarihi ipek böcekçiliği evi, ziraat evi ve eski belediye binası alanlarının çevresindeki sert zeminlerin toplam alan miktarı yaklaşı $1.000 \mathrm{~m}^{2}$ 'dir. Karaalioğlu Parkı'nın toplam sert zemin alanı ise yaklaşık olarak $32.500 \mathrm{~m}^{2}$, dir. 
Karaalioğlu Parkı Cumhuriyet döneminde yapılan toplam yeşil alan miktarı yaklaşık olarak $36.500 \mathrm{~m}^{2}$ 'dir. Bu alanlar dışında kalan çocuk oyun alanları ve ortak yaşam alanlarının kapladığı alan miktarı yaklaşık olarak $6.500 \mathrm{~m}^{2}$ 'dir. Ayrıca Çimrin (2006) tarafından bildirildiğine göre; Çimen ve çiçeklik alanı için $30.000 \mathrm{~m}^{3}$ toprak getirtilmiştir. Karaalioğlu Parkı'nın yeşil alan kullanımları günümüzde de erken Cumhuriyet dönemi bitkisel tasarım anlayışından çoğunlukla izler taşımaktadır. Ankara ve diğer illerde tasarlanan Cumhuriyet parklarındaki gibi yürüyüş akslarının ortalarında bitki parterleri yer almaktadır. Bitki parterlerinde genellikle klasik tarzda süslemelerin olduğu yer örtücü bitkiler kullanılmıştır. Tasarlanan yollar ve süsleme biçimleri Barok, Rönesans dönemi bahçelerinden de izler taşımaktadır.

Park Cumhuriyet döneminin ilk eserlerindendir. Parka bu dönemde Cumhurbaşkanı olan İsmet İnönü’nün adı verilmiştir. Parkın kuruluşunda batı girişinde İnönü Parkı yazılı 1şıklı bir tabela ile vurgulanmıştır. Doğu girişinde ise Gazi Bulvarı yazan 1şıklı bir tabela bulunmaktadır (Şekil 4). İki galvaniz boru üzerine tutturulmuş ve kaligrafik olarak yazılmış parkın adı, yeni Türk alfabesinin ve Cumhuriyetin simgelerinden sayılmıştır.
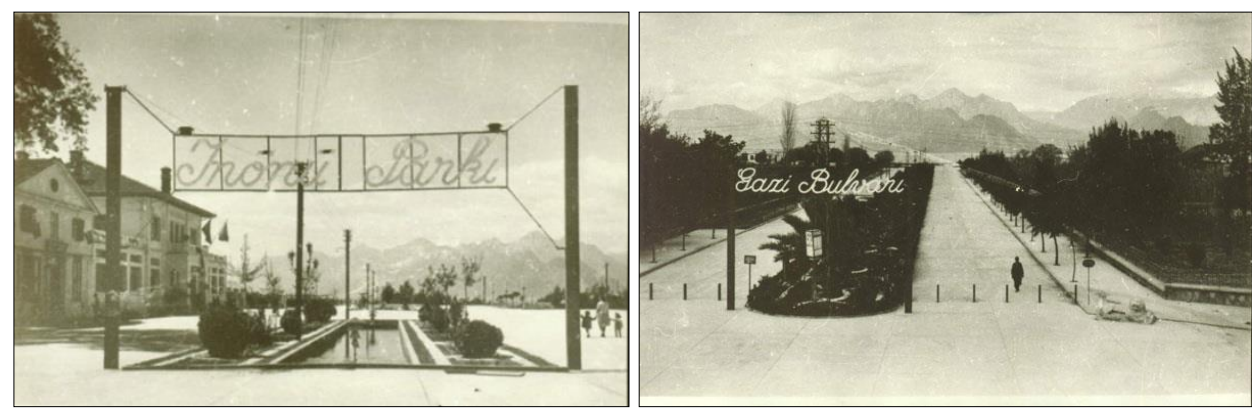

Şekil 4. Parkın 1940 yılındaki batı ve doğu girişlerinin görüntüsü (Anonim, 2017a)

Erken Cumhuriyet döneminde parkta kullanılan aydınlatma elemanları küçük, orta ve büyük boy olarak farklı kategorilerde alanın birçok noktasına tesis edilmiştir. Parktaki aydınlatma elemanları, dönemin tasarım anlayışına uygun olarak, kimi zaman rüstik bir yapıda, kimi zamanda doğadan ilham alan tasarımlarla hayat bulmuştur (Şekil 5). Fakat aydınlatma elemanları değișen yerel yönetimlerle birlikte yerini daha modern ve teknolojik olanlarına bırakmıştır. Günümüze baktığımızda ise donatı elemanlarının bugün neredeyse tamamı yok olmuş durumdadır.
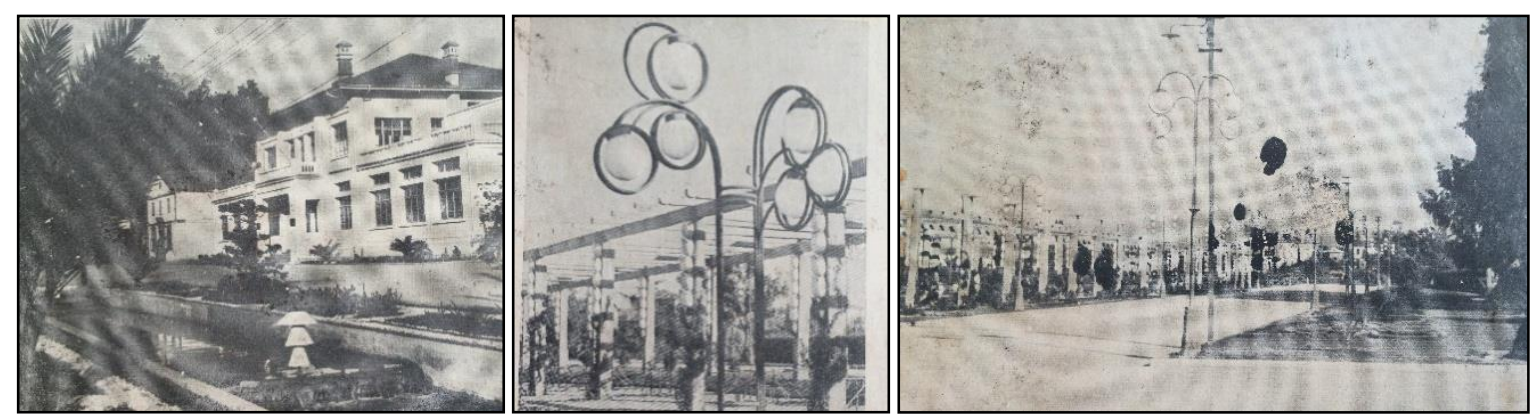

Şekil 5. Parkın ilk döneminde kullanılan kısa boylu, orta boylu ve uzun boylu aydınlatma elemanları (Vâ-Nû, 1944)

Karaalioğlu parkında kullanılan su yapıları geometrik formlarda ve genel olarak su kanalları şeklinde tasarlanmıştır. Alanın Kuzeybatı girişinden itibaren su kanalları yürüyüş akslarının ortalarında yer almıştır. Yürüyüş akslarının ikiye bölündüğü kısımda ortada büyük fiskiyeli bir havuz inşa edilmiştir. Ayrıca yaz aylarında ailelerin serinlemek amaçlı kullandıkları yüzme havuzu alan içerisinde merkezi bir noktada konumlandırılmıştır (Şekil 6). 


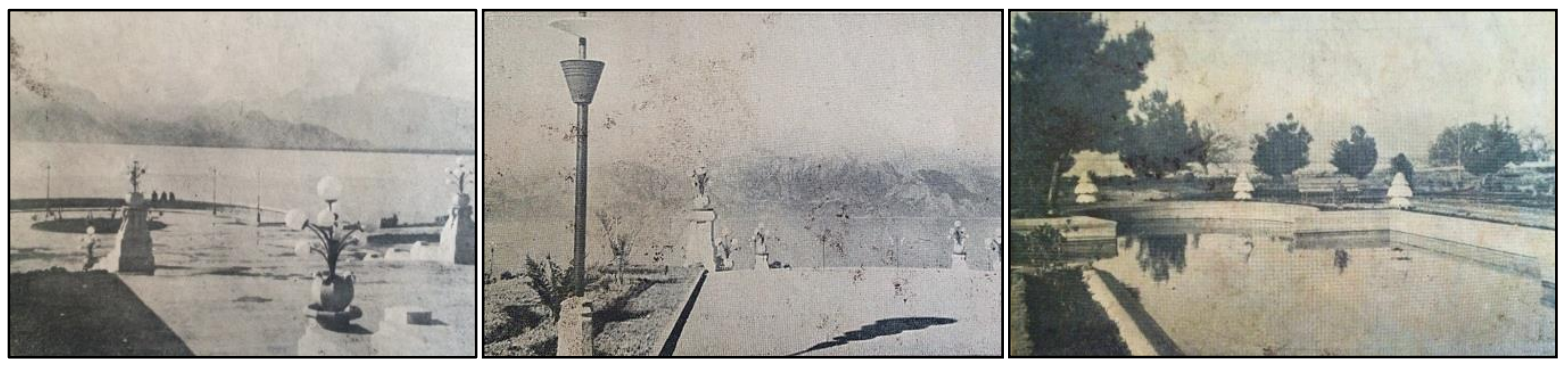

Şekil 6. Karaalioğlu Parkı orta miradordan bir görüntü ve Karaalioğlu Parkı yüzme havuzu (Vâ-Nû, 1944)

Karaalioğlu parkı, içerisinde barındırdığı çok sayıda farklı bitki türleriyle, Antalya kent merkezinde adeta küçük bir botanik bahçesi olma niteliği taşımaktadır. Park alanında geçmişten günümüze ulaşabilmiş anıtsal nitelikte birçok tür bulunmaktadır. Karaalioğlu parkı içerisinde tespit edilen kuruluştan beri yaşayan anıtsal ve ana omurgayı oluşturan ağaçlar; Arokarya (Araucaria araucana), Kızıl Çam (Pinus brutia var. brutia), Fıstık Çamı (Pinus pinea), Doğu çınarı (Platanus orientalis), Çitlembik (Pistacia terebinthus subsp. palaestina), Erguvan (Cercis siliquastrum), Hurma (Phoenix dactylifera), Manolya (Magnolia grandiflora), Palmiye (Washingtonia filifera), Toros Sediri (Cedrus libani var. Libani), Akdeniz Servisi (Cupressus sempervirens var. sempervirens \& var. horizontalis) ve Zeytin (Olea europea)'dir (Şekil 7).
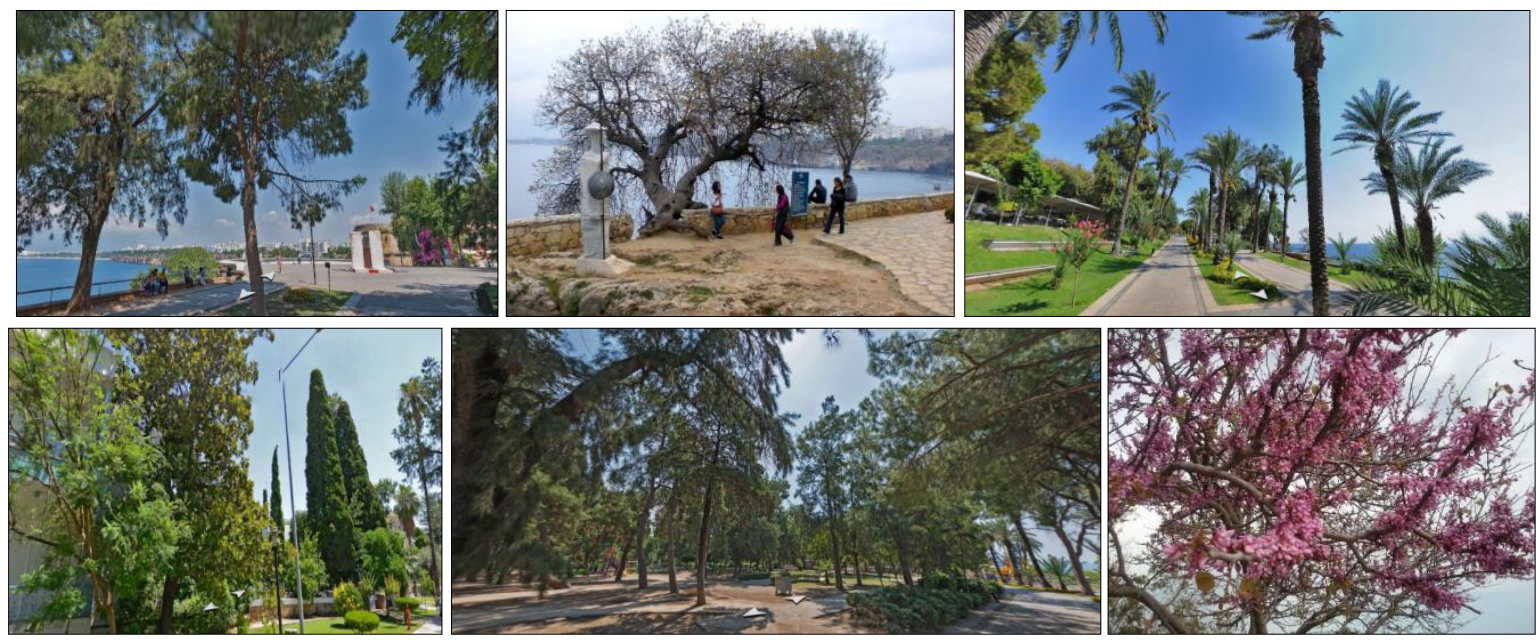

Şekil 7. Karaalioğlu parkında bulunan bitkilerden genel görünüm

\subsection{Karaalioğlu Parkı Modern Dönemde Yapılan Çalışmalar}

Antalya Karaalioğlu Parkı alanı ve çevresinin kentsel tasarımı ve koruma projeleri Antalya Büyükşehir Belediye Başkanlığ 1 tarafından 01/07/2002 tarihinde "Bayındırlık ve İskan Bakanlığ Mühendislik ve Mimarlık Proje Yarışmaları Yönetmeliği" kuralları çerçevesinde, serbest, ulusal ve tek aşamalı olarak yarışmaya çıkartılmıştır. Yarışma Mimarlar Odası Antalya Şubesi’nin danışmanlığında düzenlenmiştir. Yarışma sonuçları 12/10/2002 tarihinde açıklanmıştır. Yarışmaya katılan projelerden sekizine ödül dağıtılmıştır. Yarışma da birinci olan ekip Hüseyin Kahvecioğlu ve Nurbin Paker Kahvecioğlu olmuştur (Anonim, 2017b).

Hazırlanan proje iki etap şeklinde uygulamaya konulmuştur. Birinci etap, alanın kuzeybatısında bulunan çocuk oyun alanlarının olduğu bölüm, miradorlar arasındaki promenad, Bülent Ecevit Kültür Merkezi çevresi ve eski pergole alanının olduğu bölümlerden oluşmaktadır. İkinci etap, tarihi belediye binası ve çevresindeki alan, eski Antalya stadının olduğu alan ve önündeki otopark alanını kapsamaktadır. İlk etap 2003-2004 yılları içerisinde uygulanmıştır. Parkın peyzaj projesini DS Mimarlık Peyzaj Mimarlığı firması hazırlamış ve yine aynı yıllar içerisinde uygulaması yapılmıştır (Anonim, 2017b) (Şekil 8,9).

Projede kullanım devamlılı̆̆ın yanında fiziki çevrenin yenilenmesi önerilmiştir. Tarihi park alanı içerisinde bulunan ve geçmişten günümüze ulaşabilmiş olan ana yaya aksları, miradorlar, mirador küpeşteleri, merdivenler, pergolalar ve havuzlar, parkın tarihi dokusuna uyularak yenilenen yapısal öğeler olmuşlardır. 


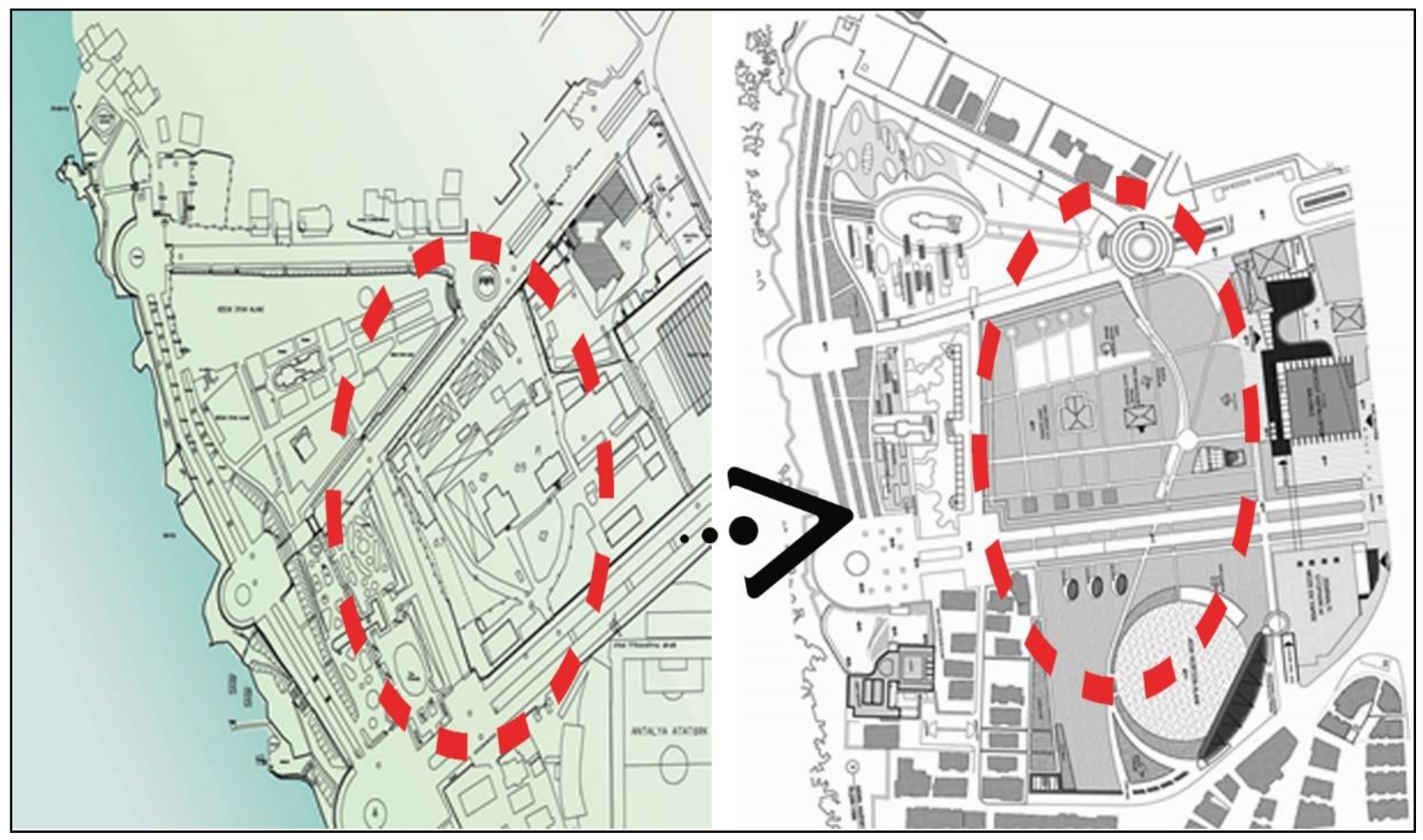

Şekil 8. Parkın önceki hali hazır planı ve yarışma ile elde edilen proje planı (Anonim, 2002).

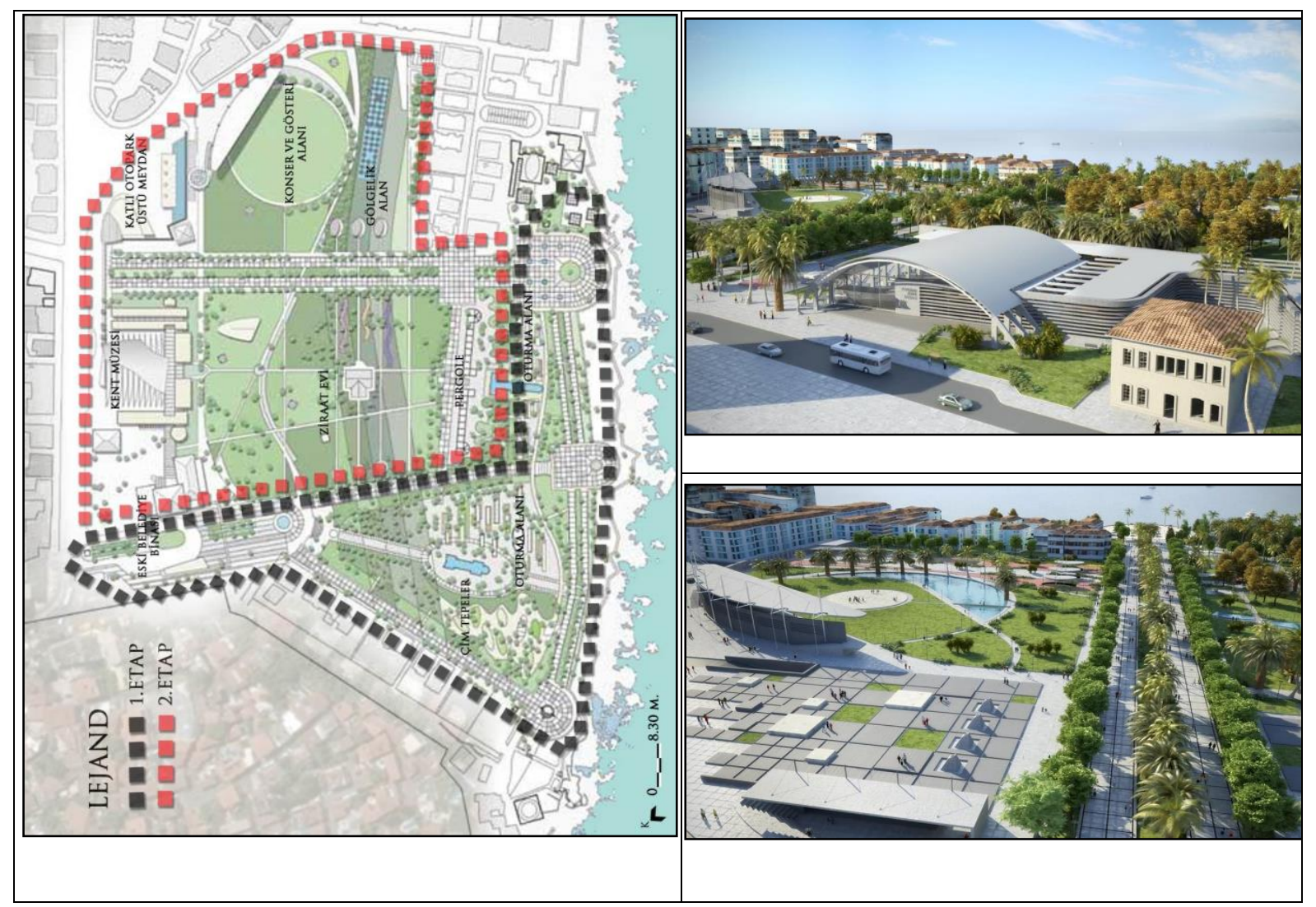

Şekil 9. Karaalioğlu Parkı'nın modern anlayışa göre tasarlanan belediye paftası ve üç boyutlu görünümler (Anonim, 2017b). 
Atatürk Stadyumu da fiziki yapısı ve kullanım devamlılığı sorunu ile projede yer almaması gereken bir yap1 olarak öngörülmüştür. Kapalı tribün, kale arkası tribün ve diğer yapısal elemanların yıkılması önerilmiştir. Elde edilen alanın parkın diğer kısımları ile bütünleştirilmesi ve çok amaçlı bir gösteri alanı olarak tasarlanması hedeflenmiştir. Kültür Merkezi, Atatürk Stadyumu'nun olduğu alanda öneri olarak geliştirilen açık gösteri alanları ile aynı paralellikte yerleştirilmiş, kültürel etkinlik ve organizasyonlara mekân oluşturması hedeflenmiştir. Eski otopark alanında yeraltı otoparkı düşünülmüştür. Ziraat evi, sosyal ve kültürel aktivitelerin gerçekleşebileceği yapı olarak gösterilmiş ve korunmuştur. Eski belediye binası, etrafındaki diğer tescilli yapılarla birlikte korunarak birbirleri ile etkileşiminin devam ettirilmesi önerilmiştir.

\subsection{Karaalioğlu Parkı Eski Belediye ve Atatürk Stadyumu Alanında Öneri Peyzaj Tasarımı}

Antalya turistik bir kent olması nedeniyle tüm dünyadan gelen turistler yanında Türkiye'nin de her yerinden vatandaşımızı ağırlayan bir kent niteliğindedir ve Karaalioğlu Parkı'da ülkenin her yerinden insanın uğramadan geçmediği bir mekândır. Dolayısıyla bu park sadece Antalya halkının değil tüm Türkiye'nin hafızasında yeri olan önemli bir parktır. Nora, Bergson, Barash gibi araştırmacıların hafıza konusundaki saptamaları, hafızanın zamana karşı direnmesinin çaba gerektirdiğini ve hafıza-mekân ilişkisinin döngüsel bir yapısı olduğunu ortaya koymaktadır (Barash, 2007; Bergson, 2007; Nora, 2006; Kayın, 2016). Parkın Akdeniz ve Beydağlarını seyretmenin ötesinde parkın kültürel değerinin de bilincine varılması bu çalışmada vurgulanmak istenen konulardandır. Bu çalışma da Karaalioğlu Parkı'nda Cumhuriyet dönemi izlerinin yeniden canlandırılması tüm ülkeden gelen vatandaşların kültürel hafızası için etkin rol oynayacaktır.

\subsubsection{Alan kullanımları}

Karaalioğlu parkı eski belediye alanı ve Atatürk Stadyumu alanının tasarımında anlamsal, işlevsel, biçimsel sorgulama ve çözümleme ilişkileri, anlama dair ve projenin başlamasında, ilk adım atılmasında majör bir karar olarak Erken Cumhuriyet döneminin park tasarım anlayışının yaşatılmasıdır. Bu karar korumacı yaklaşımının anlamsal sorgulama, çözümleme çalışması sonucu ortaya çıkmıştır. Bu çözümlemede Erken Cumhuriyet dönemi parkı olan Karaalioğlu parkında geçmişe dair özelliklerin yaşanmış olmasının katkısı bulunmaktadır.

Diğer çözümleme yaklaşımı olarak; zihinde bu anlamsal verinin türetilmesinde Erken Cumhuriyet dönemi parklarındaki simetri ve park tasarımında alan yoğunluğunun dikkat çekici olduğu gözlemlenmiştir. Anlamsalbiçimsel sorgulamalar ve çözümlemeler sonucu ortaya çıkan geometrik formlu yeşil alanlar işleve dair ayrı bir sorgulama çözümleme işlemine tabi tutulduğunda mevcut yapısal elemanları korumacı anlayışın bir temsilcisi olarak müze işlevi kazandırılması planlanmıştır. Alanın geçmişe dair taşıdığı anlam müzik, tiyatro, sinema gibi görsel sanatlarla işlevlendirmek amacıyla yapısal eleman unsuru olarak amfi tiyatro projeye eklenmiştir .

Alanın yoğun kullanım mevsimi genellikle yaz aylarıdır bölge iklimi sıcak ve nemlidir. Kentte ve yakın çevresine özellikle bu aylarda hizmet verebilecek stabil ve hareketli su yüzeyleri az sayıda bulunmaktadır. Kentin bu yöndeki büyük eksikliğini giderecek uygun ölçekte ve dönemin tarzına uygun su yapıları tasarlanmıştır. Bu su yapılarının etraflarında pasif ve aktif rekreasyon etkinliklerine yer verilebilecek tesisler tasarlanmıştır. Alandaki tesislerden oturma bölümleri, pergola alanı ve diğer dinlenme alanları gürültüsüz yerlerde seçilmiştir. Amfi tiyatro alanı ve tarihi yapılar alanın belirli bir yerinde kentten izole edilmiş ve işletmesi kendi içlerinde olacak şekilde tasarlanmıştır.

\subsubsection{Sirkülasyon çalışmaları}

Karaalioğlu parkı eski belediye ve Atatürk stadyumu alanında öneri olarak geliştirilen, alan içi genel yürüyüş aksları ve ara yollar dönemin peyzaj mimarlığı anlayışına göre düz, ışınsal ve keskin hatlarla tekrar oluşturulmuştur. Sirkülasyon sistemi, ana girişler ve diğer girişler birbiriyle bağlantılı olacak şekilde ve alanda fonksiyonel olarak üst düzey yarar sağlayacak biçimde tasarlanmıştır. Ana yollar uzun, düz ve kısa yollarla kullanım birimleri ana sirkülasyon ağına bağlanmış, böylece kullanım alanlarının parçalanması önlenerek yeşil alanlar kazanılması sağlanmıştır. Alan içerisindeki araç yolları kontrollü olarak Doğu ve Batı kapısından verilmiştir. Ayrıca alan içerisinde bisiklet yolu, gezinti amaçlı uzun promenad yolları tasarlanarak kullanıcıların tesisler haricinde spor ve gezinti amaçlı kullanabilecekleri bir sirkülasyon sistemi hedeflenmiştir. Yürüyüş yollarında malzeme uyumluluğun sağlanması ve Eski Cumhuriyet dönemindeki malzeme kullanımına atfen beton dökme plaklar ve doğal taşlar tercih edilmişsir.

Karaalioğlu parkı eski belediye ve Atatürk stadyumu alanında öneri olarak geliştirilen, alan içi genel yürüyüş aksları ve ara yollar dönemin peyzaj mimarlığı anlayışına göre düz, 1şınsal ve keskin hatlarla tekrar oluşturulmuştur. Malzeme uyumluluğun sağlanması ve dönemin malzeme kullanımına atfen beton dökme 
plaklar ve doğal taşlar tercih edilmiştir. Alandaki toplam sert zemin ve yürüyüş yolları alanı yaklaşı olarak $11.000 \mathrm{~m}^{2}$, dir

\subsubsection{Yeşil alan sistemleri çalışması}

Karaalioğlu parkı bitkilendirme tasarımı ve yeşil ağ sistemi planı yapılırken aynı tarihlerde yapılmış diğer illerdeki projelerden ilham alınmıştır. Özellikle dönemin Barok ve Rönesans bahçe sanatına atıflarda bulunan bu tarz, parkın yeşil alan sistematiğinin oluşturulmasında etkili olmuştur. Düzgün çiçek parterleri, aksları kesen geometrik formlar ve simetrik görüntü oluşturan çiçek düzenlemeleri ile dönemin tarzına uygun bir plan elde edilmiştir. Elde edilen toplam yeşil alan miktarı $31.000 \mathrm{~m}^{2}$ 'dir (Şekil 10).
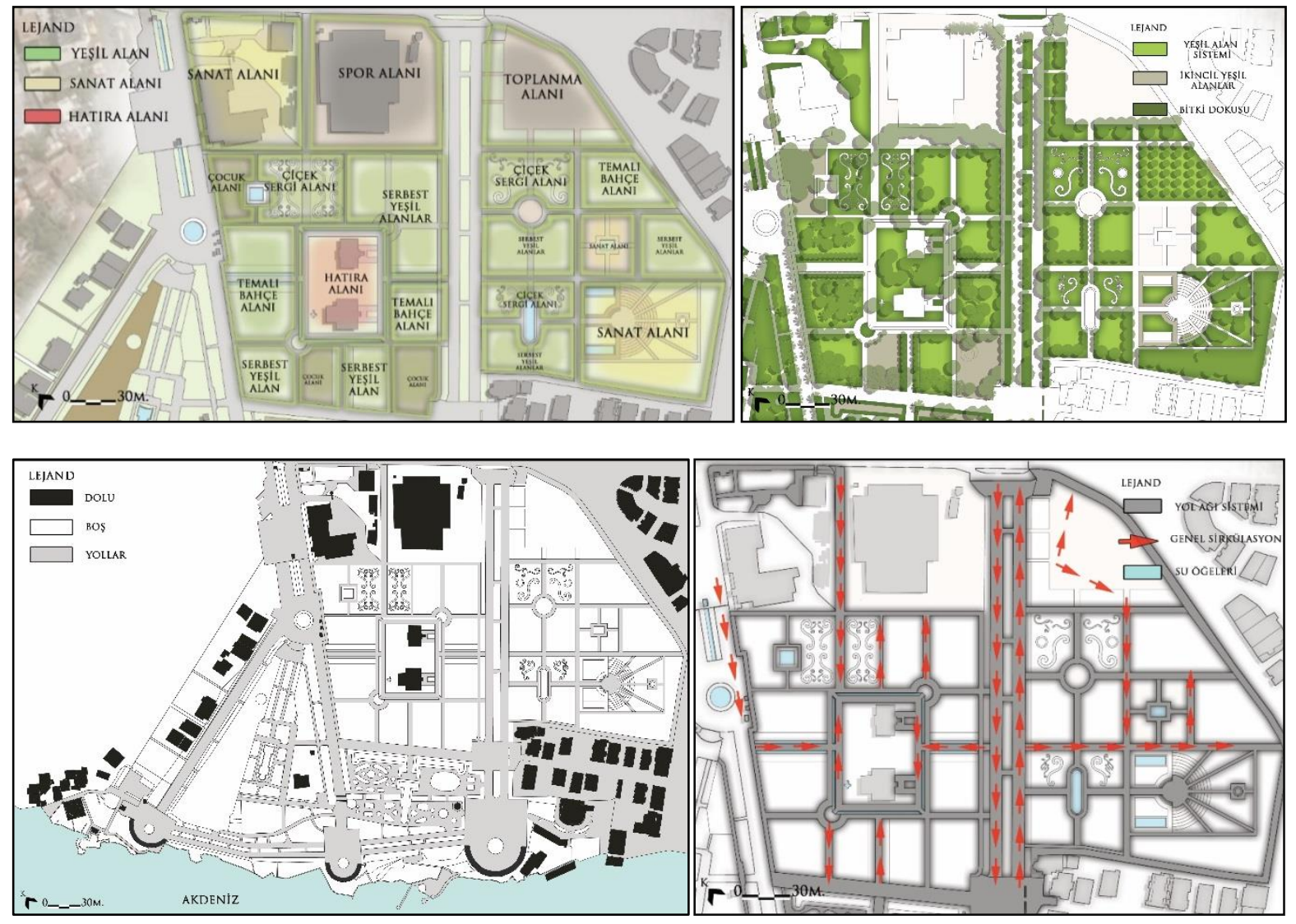

Şekil 10. Karaalioğlu Parkı alan kullanım plânı (A), yeşil alan sistemi planı (B), doluluk-boşluk ilişkisi planı (C), yol ağı planı (D)

Karaalioğlu parkının bitkisel tasarımında genellikle Akdeniz yöresine ait türlerin kullanımı tercih edilmiştir. Alanın güneyinde amfi tiyatro alanının tamponlanması amacıyla Cedrus sp., Pinus sp.ve Cupressus sp. türlerine ağırlıklı olarak yer verilmiştir. Görsellik ve form dokusu oluşturması amacıyla alanın Kuzey ve Doğu konumlarında Buxus sp. ve Taxus sp. türlerinin kullanımına yer verilmiştir. Alanın Güneybatısında gölge amaçlı Platanus orientalis kullanılmıştır. İkincil yeşil alanlarda ve çocuk oyun alanlarında genellikle herdem yeşil ve risk unsuru oluşturmayan türlerin kullanılması planlanmıştır. Vasfını yitirmekte olan ağaçların tespit edilerek yerine aynı boylarda yeni ağaçların getirilebilmesi için bitki üretilmesi fikri oluşturulmuştur. Bu amaçla alandaki Cumhuriyet dönemi bitki dokusu korunmuş olacak ve görsel olarak yaşamaya devam edecektir. Ayrıca çalışma alanında narenciye ağaçlarının yer aldığı bazı parseller oluşturulmuştur. Bu parsellerin estetik olarak alana renk katması hedeflenmiş ve halka açık yenilebilir bir peyzaj öğesi olması düşünülmüştür.

\subsubsection{Doluluk-boşluk sistemleri çalışması}

Çalışma alanı içindeki tarihsel değerinden dolayı koruma önemi olan Ziraat evi, İpekböcekçiliği evi, Atatürk evi ve Eski Belediye binası kitlesel doluluk olarak yer almaktadır. Karaalioğlu parkı içerisinde mevcutta bulunan tarihi yapılar korunarak, sosyal ve kültürel faaliyetlerde kullanılmak üzere tekrar hizmete alınması planlanmıştır. Eski belediye binası sinema müzesi, ipekböcekçiliği evi ipekböcekçiliği müzesi ve ziraat evi ziraat müzesi olarak Cumhuriyet dönemi hatıralarının yeniden yaşatılması hedeflenmiştir. Buna ek olarak açık 
gösteri alanına hitap eden amfi tiyatro, parkın fonksiyonunu arttıran bir eleman olarak alana hizmet etmesi amacıyla eklenmiştir.

Bitkisel alanlardaki döneme ait alanın iskeletini oluşturan sağlıklı ve koruma değeri yüksek ağaç kitlelerinin olduğu alanlar beton alanlara alternatif doluluk niteliği taşımaktadır. Projede parkın ilk yapıldığı dönemdeki yeşil alanlar korunmuş ve bu alanların betonlaştırılmaması için yeni bir yapı kitlesi düşünülmemiştir. Projesinin bütününde 1/3 oranında yapı kitlesi, 1/3 oranında bitki kitlesi ve $1 / 3$ oranında ulaşım, çim alan ve su yüzeylerini içeren açık alan oluşturulmaya ve projede boşluk doluluk dengesi sağlanmaya çalışılmıştır.

\subsubsection{Avan proje tasarım kararları}

Karaalioğlu parkı giriş akslarının hemen başında, parkın adının yazıldığı ve bulvar isimlerinin yer aldığı tabelalar çeşitli kaynaklardan elde edilen görseller sayesinde tespit edilmiş ve benzer bir giriş tasarlanmıştır.

Karaalioğlu park alanında geçmişte 7 adet havuz inşa edilmiştir. Alan içerisindeki havuzlarla birlikte tüm havuzların gerekli bakımlarının yaptırılıp Cumhuriyet dönemini yansıtacak donatılarla geliştirilerek tekrar hizmete sunulması hedeflenmiştir. Tasarım alanı içerisinde bulunan havuzlarda geometrik ve genellikle dairesel formlar, 1şıklar ve fıskiyeli sistemler tercih edilmiştir.

Cumhuriyet döneminin getirdiği pek çok yenilikle birlikte mimari alanında da eski dönemin izlerinden farklı yeni söylemler sunmaktaydı. Gerek yerli gerek yabancı birçok tasarımcı bu yeni akıma ayak uydururken beraberinde bir tarzın oluşmasına da katkı sağlamışlardır. Barok ve Rönesans bahçe süsleme sanatından da çeşitli izler taşıyan bu tarza uygun, simetrik, informal şekillerde bezenen süs bitkileri alanda sıklıkla kullanılmıştır.

Alanda, Cumhuriyet dönemi tarzına uygun malzeme ve donatılarla geliştirilmiş 110 kişilik açık sahne alanı ve amfi tiyatro tasarlanmıştır. Sahne 6 farklı ışınsal yolla mevcut alana bağlanmıştır. Alanın girişinde simetrik olarak bitki düzenlemelerine ve su öğelerine yer verilmiştir. Alanın güneyinde ve doğusunda, gürültü kirliliğinin yakındaki yerleşim yerlerine rahatsızlık vermemesi adına koruluk planlanmıştır (Şekil 11).

Cumhuriyet döneminde heykel sanatı dönemin zorluklarını anlatmayı hedeflemiş, kurtuluş ve özgürlük gibi simgeleri gelecek nesillere aktarmayı planlamış bir sanat dalı olmuştur. Bu bağlamdan yola çıkılarak sahne alanının kuzeyinde Cumhuriyet rejimini yansıtan ve içerisinde o dönemden öğretiler barındıran farklı heykellerin ve plastik objelerin kullanılması düşünülmüş, farklı sanatçıların bir araya gelmesi hedeflenmiştir.

\section{Tartışma ve Sonuç}

Paper İtalyan Camillo Boito restorasyon konusunda daha önce ileri sürülen ve her biri ayrı bir bakış açısının parçalı görüşünü getiren üslup birliği, romantik görüş ve tarihi rekompozisyon kuramlarını çağdaş restorasyon anlayışı içinde uzlaştırıp birleştirmiştir. Daha sonrada Giovannoni restorasyonların daha bilimsel yapılmasını ve anıtların çevre dokularıyla birlikte korunmaları görüşünü savunmuştur. Bu gelişmeler 1931'de Atina'da toplanan "Tarihi Anıtların Korunması ile İlgili Mimar ve Teknisyenlerin I. Uluslararası Konferansı"nda uzmanlar tarafından tartışılmış ve benimsenmiştir. Bu belgede öne çıkan ve çalışma konumuz kapsamında önem arz eden maddeler şöyle sıralanmıştır; "Tarihi anıtların çevrelerine saygı gösterilmeli, hatta bazı yapı kümeleri ve pitoresk oluşumlar korunmalıdır. Tarihi anıtların onarımında çağdaş tekniğin sunduğu bütün olanaklar akıllıca kullanılmalıdır. Yapısal çevrelerin yaşamlarını sürdürebilmeleri için kullanıma açık olmaları gerekir, ancak bu kullanım onların tarihi ve estetik kimliklerine saygılı bir amaca dönük olmalıdır" (Ahunbay, 2009). Bu maddelerden yola çıkılarak üzerinde çalıșma yapılacak olan tarihi alanların kullanımına devam edilebilmesi için, öncelikli olarak yapılı çevrenin ve yeşil alanların aslına uygun olarak planlanıp tasarlanması benimsenmelidir.

Venedik Tüzüğü’nün 5. maddesinde, “Anıtların korunması, her zaman onları herhangi bir yararlı toplumsal amaç için kullanmakla kolaylaştırılabilir. Bunun için bu tür bir kullanma arzu edilir, fakat bu nedenle yapının planı, ya da bezemeleri değiştirilmemelidir. Ancak bu sınırlar içinde yeni işlevin gerektirdiği değişiklikler tasarlanabilir ve buna izin verilebilir" denilmektedir (Erder, 1964).

20. yüzyılın üç çeyreğini kapsayan ve 21. yüzyıla uzanan Cumhuriyet dönemi mimarlık ürünlerinin ise "kültürel miras" olarak potansiyellerinin değerlendirilmesi, mimarlık ve onun bir alt alanı olarak ifade edilebilen koruma alanının yeni sorunsallarından birini teşkil etmektedir. Bu sorunsal, Erken Cumhuriyet dönemi mimarlık 
ürünlerinin bir bölümünün koruma statüsüne alınmış olması dolayısıyla, eskiden beri var olan bir tartışmaya işaret etmekte olsa da, konunun şu an itibarıyla yeni bir içerik ve yaklaşımla ele alınmasının gerektiği kuşkusuzdur.

Cumhuriyet dönemi mimarlı̆̆ının miras statüsü konu edildiğinde, yaygın olarak Erken Cumhuriyet dönemindeki tarihsel referanslı mimarlığa odaklanma eğilimindeki koruma anlayışının, yerini "geride bıraktığımız her anın tarihe dâhil olduğu” kavrayışıyla geliştirilecek farklı bir yaklaşıma ivedilikle bırakması gerekmektedir (Kayın, 2007). Bu bağlamda koruma anlayışının, bir alanın tarihi yaşanmışlığı ne kadar eski ise o derece ihtimam gösterilmesinin yanlış olduğundan bahsedilmektir. Ülkemizde ise yapılan uygulamalar bu yaklaşımdan oldukça uzakta olduğumuzu göstermektedir. Kültürel değerlerin ihtiyaca cevap verecek bir yenileme anlayışından uzak niteliksiz ve kimliksiz değişimi çevresel estetiğin kültürle birlikte yok olduğunu göstermektedir.

Dünya 20. yüzyılın son dönemlerinde modernite anlamında büyük bir gelişim ve değişim göstermiştir. Bu değişim teknolojik ilerlemelerin merkez alındığı pozitivist ve rasyonalist bir anlayışla gerçekleşmiştir. Modernizmin neden olduğu ilerlemenin yerini doldurmak ise bu dönemde ne yazık ki mümkün olamamıştır. Nitekim modernizmi takip eden bu post modern dönemde ülkemizde de büyük değişimler yaşanmasına rağmen toplumu Erken Cumhuriyet döneminde olduğu gibi tasarımcılar ve mekân yoluyla eğitme projesinin yerine yenisi konulamamıştır.

Karaalioğlu Parkı da bu değişimlerden nasibini almış bir mekandır. Bu park Erken Cumhuriyet döneminde Batı Akdeniz bölgesinde kent olmaya çalışan Antalya'da kentte yaşayanları modern bir topluma dönüştürmeyi amaçlayan söylemin mimari bir ürünü olarak ortaya çıkan bir sosyalleşme mekanıdır. Toplumun ulus bilinci yanında doğa sevgisini oluşturmak bu anlamdaki pratikleri üretmek ve dönüştürmek amacının zamanla terkedildiğini, Karaalioğlu Parkı'nın son dönemdeki fiziksel durumu üzerinden gözlemek mümkündür. Parkta yapılan yeni post modern düzenlemeler böyle bir eğitsel görevi üstlenecek nitelikte değildir.

Erken Cumhuriyet dönemi peyzaj mimarlığı anlayışı ile Karaalioğlu Parkı üzerinde yapılan tasarım çalışmaları ile parkta bulunan geçmişteki izlerin gelecekteki hatıralara iz bırakabilmesi hedeflenmiştir. Proje çalışmalarında Cumhuriyet değerlerine saygı gösterilmesi, ilerleyen zamanda yapılacak olan çalışmalara örnek olması hedeflenmiştir.

Bugün ABD'de New York'un simgesi Central Park'ın alanı 3,41 km², İngiltere'de Londra'nın simgesi Hyde Park alanı 2,53 $\mathrm{km}^{2}$ ve Almanya'da Berlin'in en önemli park1 Tiergarten Park alanı ise toplam 2,1 km ${ }^{2}$ 'dir. Turizm başkenti olarak lanse edilmekte olan Antalya'da bulunan Karaalioğlu Park alanı ise $0,12 \mathrm{~km}^{2}$ büyüklüğünde bir alana yayılmaktadır. Bu ölçütlerden yola çıkılarak günümüz yerel yönetimlerinin kentli yaşamının konforunu dikkate alarak kent içerisinde kişi başına düşen yeşil alan miktarını artırabilmek için çaba göstermesi gerekmektedir. Bunun da kentsel dönüşüm ve kentsel iyileştirme firsatlarında yeşil alan artırmayı hedeflemekle üstesinden gelinebilir.

Sürekli turizmin başkenti olarak ifade edilen Antalya'da son dönemde yaşanılan ekonomik kriz sadece ekonomik çıkarlarla bir kentin ayakta kalamayacağının iyi bir göstergesi olmuştur. Bir kenti sadece deniz, kum ve güneş değerlerine indirgemek tarihi ve kültürel değerleri, içinde yaşadığı halkı unutup yok saymak ve sadece kenti deniz, kum ve güneş için kente gelen turistler açısından değerlendirmek oldukça yanlış bir yaklaşımdır.

$\mathrm{Bu}$ anlayış yüzünden kentin bütün açık ve yeşil alanları turizm amaçlı kullanılmaktadır. Aynı eğilim kent içinde de yeşil alanların rant yüzünden betonlaşması ile devam etmektedir. Bu tarihi ve kültürel önemi bulunan Karaalioğlu Parkı içinde benzer özellik göstermektedir. Karaalioğlu Parkı bir yeşil alan olarak varlığını sürdürmelidir. Bu park çevresindeki Kaleiçi ve Balbey gibi tarihi kent merkezlerinin akciğeri niteliğinde bir yeşil alan olarak betonlaşmadan kente hizmet etmelidir (Tablo 2).

Yaşam koşullarının, geleneklerin, yapım tekniklerinin, malzemelerin ve alan kullanımlarının hızla değiştiği içinde bulunduğumuz koşullarda, tarihi parklar geçmişte nasıl bir çevre içinde yaşandığını gösteren açık hava müzeleridir. Tarihi parkları incelemek bize geçmişteki tasarımcıların tasarım çözümlerine, yaratıcılığına ilişkin ipuçları vermekte bugün tasarlaması olanaksız mekanların arka planında duran yaratıcı kaynağın gücünü anlamamız için olanak sağlamaktadır. İçinde yaşayanlar yok olsa bile tarihi mekanların yaşıyor olması ve gelecek kuşakların onları hissetmesi sağlıklı bir gelecek için oldukça önemlidir. 

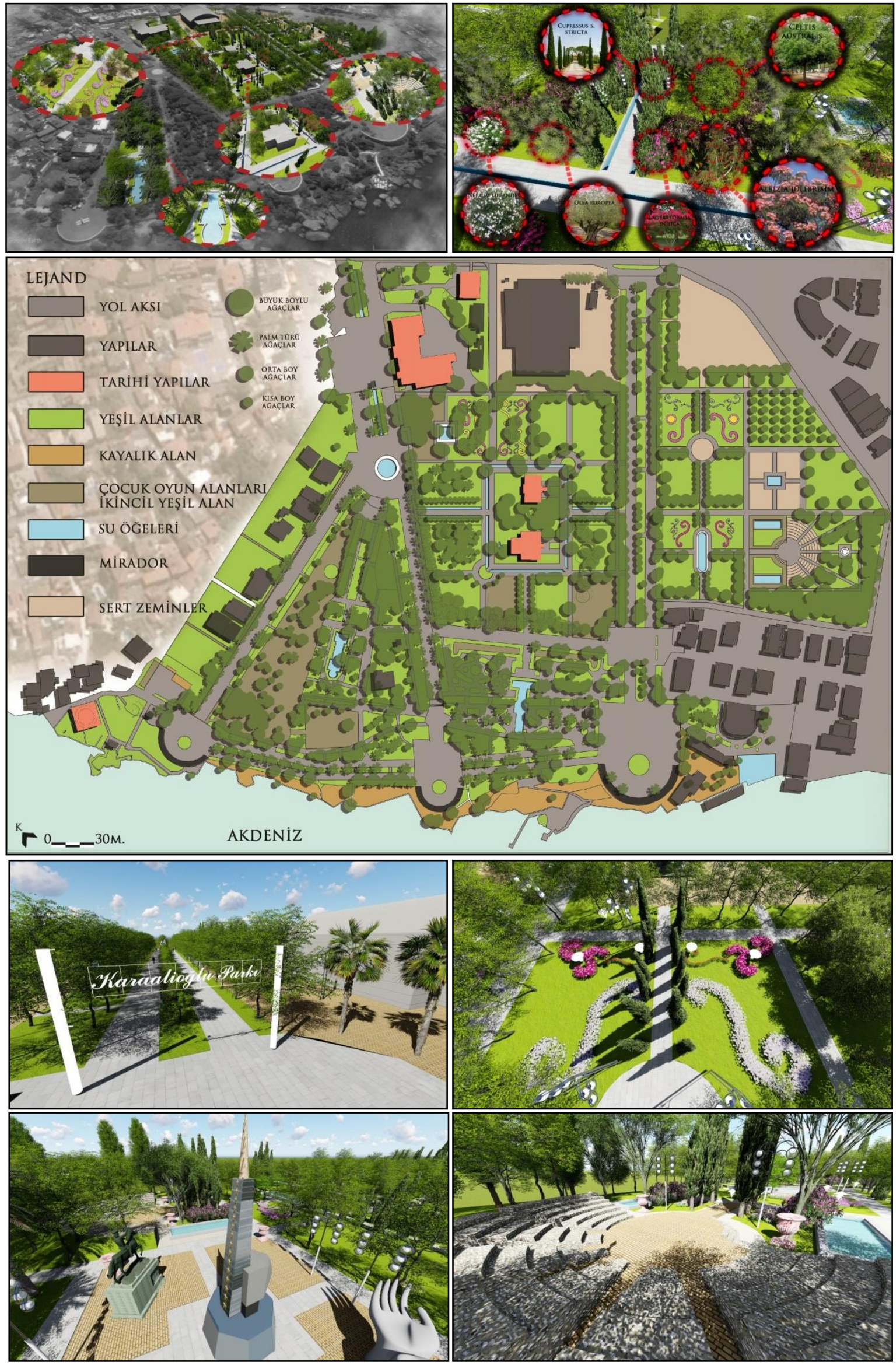

Şekil 11. Karaalioğlu Parkı Cumhuriyet anlayışına göre hazırlanmış avan proje ve üç boyutlu görseller 
Tablo 2. Uygulanmış ilk proje, yarışma projesi ve Erken Cumhuriyet Dönemi anlayışına göre hazırlanan projenin genel metrajları

\begin{tabular}{|c|c|c|c|c|}
\hline Uygulanan İlk Proje & \multicolumn{2}{|c|}{$\begin{array}{l}\text { Yarışma Sonucunda Uygulanan } \\
\text { Proje }\end{array}$} & \multicolumn{2}{|c|}{$\begin{array}{l}\text { Erken Cumhuriyet Dönemi } \\
\text { Anlayışına Göre Yapılan Proje }\end{array}$} \\
\hline Yapisal Alan & Yapisal Alan & Yeşil Alan & Yapısal Alan & Yeşil Alan \\
\hline $30.000 \mathrm{~m}^{2}$ & $75.000 \mathrm{~m}^{2}$ & $51.000 \mathrm{~m}^{2}$ & $53.800 \mathrm{~m}^{2}$ & $72.200 \mathrm{~m}^{2}$ \\
\hline Toplam alan: $\quad 69.290 \mathrm{~m}^{2}$ & Toplam alan: & $126.000 \mathrm{~m}^{2}$ & Toplam alan: & $126.000 \mathrm{~m}^{2}$ \\
\hline $\begin{array}{l}\text { İlk dönem projesinin \% 56’sı } \\
\text { yapısal alan \% 44'ü yeşil } \\
\text { alanlardan oluşmaktadır }\end{array}$ & \multicolumn{2}{|c|}{$\begin{array}{l}\text { Yarışma ile yapılan projenin \% 59'u } \\
\text { yapısal alan \% } 41 \text { 'i yeşil alanlardan } \\
\text { oluşmaktadır }\end{array}$} & \multicolumn{2}{|c|}{$\begin{array}{l}\text { Erken Cumhuriyet anlayışına göre } \\
\text { yapılan projenin } \% 42 \text { 'si yapısal alan } \\
\% \text { 58'i yeşil alanlardan oluşmaktadır }\end{array}$} \\
\hline
\end{tabular}

Erken Cumhuriyet dönemi tasarımları herkes tarafından beğenilmeyebilir. Ancak tamamen ortadan kaybolmasını önlemek tüm toplumun menfaatinedir. Özellikle kültürel birikim içinde her dönemi ya da farklı dönemleri yansıtan tasarımların çeşitliliği arzu edilen bir durumdur. Özellikle de tek tip dijitalleşmeye doğru giden tüm duyusal tecrübe, tüm dışavurumun aynı şekilde kodlandığı günümüz koşullarında bu çeşitlilik bu eğilimin karşısında durmaktadır.

Mevcut park dokusu içerisinde, programı yoğun, iri kütleli yeni binalar yapılarak dokunun ölçeğini bozmamak gerekir. Yeni tasarımları için alan yaygın arsa kullanım oranlarına, kütle boyutlarına, mimarinin genel çizgilerine uygun dolgu yapılması gerekir. Alandaki analiz çalışmaları sırasında belirlenen tipolojiden yola çıkılarak yeni bina tasarımları yapılması başarılı bir çözüm olabilir. Yapı cephelerindeki doluluk boşluk oranlarının, kullanılan renk ve malzemenin, çatı biçiminin alana uygun olması yeni tasarımın çevreyle bütünleşmesi açısından önemlidir.

Parkın genel görünümüne egemen bir veya birkaç anıt, yapı, ağaç, giriş takı, kamelya gibi tekrar eden öğelerin bir araya gelmesiyle park için tanımlayıcı bir özellik taşıyan park silueti oluşur. Parkın alan kullanımlarının temel öğelerinden vazgeçilmesinin söz konusu olmadığı gibi onların bir araya gelmesiyle oluşan genel görünümde ait olduğu parkla özdeşleşen bozulması istenmeyen bir imgedir.

Erken Cumhuriyet döneminin parklarının korunması ve gelecek kuşaklara kalmasının toplumsal hafiza açısından önemini vurgulayan bu araştırma bundan 50 yıl sonra Expo 2016 fuar alanının korunması için yeterli bilince sahip gelecek kuşaklara bir farkındalık oluşturmayı dilemektedir.

Cumhuriyetin kamusal mekân modellerinin ve onların temsil ettiği modernleşme eğiliminin günümüzde de etkin rol oynadığı görülmektedir. Günümüz parkların da yerel yönetimlerin taşıdığı mekânsal sorumluluğun önemi tartışılmazdır. Modernleşme, yenilikçi düşünceler ve tasarımlar, hızla büyüyen kentlerin yeni imara açılan yerleşimlerin içinde yer bulması, tarihi ve kültürel önemi olan parkların ise özgün değerlerini koruması ve yaşatılması için gereğinin yapılması gerekmektedir. Bu kapsamda toplumsal inisiyatifin, toplumsal duyarlılığın geliştirilmesi her şeyin ötesinde bir aciliyet taşımaktadır.

\section{Teşekkür}

Bu çalışma, Akdeniz Üniversitesi, Fen Bilimleri Enstitüsü, Peyzaj Mimarlığı Anabilim Dalı’nda yürütülen ‘Cumhuriyet Dönemi Kent Parklarının Karaalioğlu Parkı Örneğinde İncelenmesi' adlı Yüksek Lisans Tezinden üretilmiştir.

\section{Kaynaklar}

1. Ahunbay, Z. (2009). Tarihi Çevre Koruma ve Restorasyon, YEM Yayın (Yapı-Endüstri Merkezi Yayınlar1), İstanbul, 188s.

2. Anonim, (2017a). http://www.fullantalya.com/hic-suphesiz-antalyanin-en-guzel-yeri-karaaliogluparkidir/ [Son erişim tarihi: 17.06.2017]. 
3. Anonim, (2017b). http://v2.arkiv.com.tr/p2681-antalya-tarihsel-karaalioglu-parki-belediye-binasi-vecevresi-kentsel-tasarim-ve-koruma-yarisma-projesi---1-odul.html [Son erişim tarihi: 17.06.2017].

4. Anonim, (2019). Karaalioğlu Park1-Muratpaşa/Antalya. https://gezilmesigerekenyerler.com/gezilecekyerler [Son erişim tarihi: 03.09.2019].

5. Anonim, (2002). Antalya Büyükşehir Belediyesi İmar ve Şehircilik Dairesi Başkanlığı

6. Arslan, E.S. (2010). Kültürel Peyzaj Kavramı Kapsamında Bir Değerlendirme: Ulus-TBMM Tarihi Aksı (Ankara). Yüksek Lisans Tezi, Ankara Üniversitesi, Fen Bilimleri Enstitüsü, Peyzaj Mimarlığı Anabilim Dalı, Ankara, 106s.

7. Baylan, R. (2003). Terkos Gölü Örneğinde Doğal ve Kültürel Çevrenin Korunması ve Geliştirilmesi Üzerine Bir Araştırma. Yüksek Lisans Tezi, Ankara Üniversitesi, Fen Bilimleri Enstitüsü, Peyzaj Mimarlığı Anabilim Dalı, Ankara, 124s.

8. Barash, A.J. (2007). Belleğin Kaynakları. Çev. Şeyda Öztürk, Cogito 50, s. 13-14.

9. Bekdemir, L.F. (2010). Kültürel Peyzaj Değerlendirmesi: Dilek Yarımadası Büyük Menderes Deltası Milli Parkı Örneği. Yüksek Lisans Tezi, Ankara Üniversitesi, Fen Bilimleri Enstitüsü, Peyzaj Mimarlığı Anabilim Dalı, Ankara, 86s.

10. Bergson, H. (2007). Madde ve Bellek. Çev.Iş1k Ergüden, Dost Kitabevi, Ankara, s.59-62, 77.

11. Bozdoğan, S. (2002). Modernizm ve Ulusun İnşas1, Erken Cumhuriyet Döneminde Mimari Kültür. Metis Yayınları, İstanbul, 367s.

12. Çınar Altınçekiç HS, Ergin B, Tanfer M (2014). Tarihsel Süreç İçinde Kent Kimliğinin Mekânsal Kalite Değerlendirmesi Üzerine Bir Araştırma (Taksim Meydanı) Artvin Çoruh Üniversitesi Orman Fakültesi Dergisi ISSN:2146-1880, e-ISSN: 2146-698X Cilt: 15, Sayı:2, 132-148

13. Çınar, H.S. (2005). İstanbul Metropolü’nde Meydanların Rekreasyonel İşlev Yönünden Önemi Üzerine Araştırmalar İstanbul Üniversitesi Orman Fakültesi Dergisi Seri A Cilt 55 Sayı1, 85-110

14. Çimrin, H. (2006). Bir Zamanlar Antalya: Tarih, Gözlem ve Anılar: Yakın Geçmişe Yolculuk. Antalya Ticaret ve Sanayi Odas1, Antalya, 640s.

15. Erder, C. (1964). Venedik Tüzüğü. http://www.icomos.org.tr [Son erişim tarihi: 10.09.2017].

16. Erdogan, R., Olgun, R,. Tulek B., Zaimoglu, Z. (2016). Investigating The Provisions of Bicycle Use and Inclinations of Riders: Konyaaltı (Antalya) Case Study. International Journal of Agriculture and Environmental Research, 2(5): 1368-1380.

17. Ingerson, A.E. (2003). Web sitesi. home.comcast.net/ jay.paul/landscapes.doc. [Son erişim tarihi: 03.09.2017].

18. Kayın, E. (2007). Cumhuriyet Dönemi Mimarlık Mirasının Belgelenmesi, Korunması ve Değerlendirilmesi Projesi için Çağrı. Mimarlık Dergisi, 334.

19. Kayın, E. (2016). İzmir Enternasyonal Fuarı ve Kültürpark İçin Bir Koruma Çerçevesi: Modern Miras, Kültürel Peyzaj ve Hafiza Temelli İrdelemeler. Ege Mimarlık, Temmuz, 10-15.

20. Nora, P. (2006). Hafıza Mekânları, Dost Kitabevi Yayınları, Ankara.

21. Olgun, R. (2019). Evaluation of Pedestrianized Streets in Terms of Landscape Design and User Satisfaction: The Case of Antalya-Şarampol Street. Journal of Bartin Faculty of Forestry, 21(2): 327-335.

22. Olgun, R., Erdoğan, R. (2016). Urban furniture and user satisfaction: The example of Antalya - Gulluk Avenue. Journal of the Faculty of Forestry Istanbul University, 66(2): 674-682. 
23. Olgun, R., Yılmaz, T. (2014). Aizanoi Antik Kentinin Peyzaj Planlama Kapsamında Korunması ve Turizm Potansiyelinin Arttırılmas1. Artium, 2(2): 122-133.

24. Özsüle, Z. (2005). Geleneksel Yerleşimlerin Korunması Açısından Kültürel Peyzaj Değerlendirmesi: Mudanya Örneği. Doktora Tezi, İstanbul Üniversitesi, Fen Bilimleri Enstitüsü, Peyzaj Mimarlığı Anabilim Dalı, İstanbul, 249s.

25. Sarı, C. (2010). Dünden Bugüne Antalya. Antalya İl Kültür ve Turizm Müdürlüğü, Antalya.

26. Sayan, S., Karagüzel, O., Ortaçeşme, V. (2000). Antalya Karaalioğlu Parkı'nın Tarihsel-Sosyal Değeri ve Kentsel Gelişimlerle İlişkisi Yönünden Değerlendirilmesi. Peyzaj Mimarlığı Kongresi 2000, Ankara, 19-21 Ekim 2000.

27. Vâ-Nû, V.N. (1944). Antalya İkinci Dünya Harbi İçinde Nasıl Güzelleşebildi?. Kenan Matbaası, İstanbul, 88s. 